\title{
Influence of Vermiwash, Panchagavya and Weed Extract on Growth, Yield and Seed Quality Parameters of Cluster Bean (Cyamopsistetragonoloba $(\mathrm{L})$.)
}

\author{
Renigunta Chainatnya ${ }^{1}$; M.Sekhar ${ }^{2 *}$; Meenakshi Joshi' ${ }^{2}$;avandlapally Rahul ${ }^{3}$; Siddhant Gupta ${ }^{3}$ \\ *Co-author email: Sekharm005@gmail.com \\ 1. M.Sc. Seed Science and Technology, SHUATS \\ 2. Asst. Professor, SDBIT, Dehradun \\ 3. Students of Agronomy, SHUATS \\ DOI: 10.47856/ijaast.2021.v08i10.007
}

\begin{abstract}
Cluster bean (Cyamopsistetragonoloba L.) popularly known as guar is a drought tolerant, deep-rooted, annual legume is grown for Vegetable, Food, Fodder, Green manure, Gum and as a seed. The fortification of seeds for better Growth and Yield has become important and emphasized. The study was conducted to determine the - Effect of Vermiwash, Panchagavya and Weed Extract on Growth, Yield and Seed Quality Parameters of Cluster bean (Cyamopsistetragonoloba (L).).The experiment was carried out at Field Experimentation Centre of the Department of Genetics and Plant Breeding, Sam Higginbottom University of Agriculture, Technology \& Sciences. Prayagraj (UP) during Kharif-2019. The experiment was laid out in Randomised Blocked Design and comprised of 13 treatments and 3 replications. The treatments were T0 (Control), $\mathrm{T}_{1}$ - vermiwash 5\% @ 12hrs, $\mathrm{T}_{2}$ - vermin wash 10\% @ 12hrs, $\mathrm{T}_{3}-$ vermiwash 15\% @ 12hrs, $\mathrm{T}_{4}$ - vermiwash 20\% @ 12hrs, $\mathrm{T}_{5}$ - panchagavya 5\% @ 12hrs, $\mathrm{T}_{6}$ - panchagavya 10\% @ 12hrs, $\mathrm{T}_{7}$ - panchagavya 15\% @ 12hrs, $\mathrm{T}_{8}$ - panchagavya 20\% @ 12hrs, $\mathrm{T}_{9}$
\end{abstract} - weed seed extract 5\%@12 hrs, $\mathrm{T}_{10}$ - weed seed extract 10\%@12 hrs, $\mathrm{T}_{11}$ - weed seed extract 15\% @ $12 \mathrm{hrs}, \mathrm{T}_{12}$ - weed seed extract $20 \% @ 12 \mathrm{hrs}$.

Keywords: Cluster beanpanchagavya, vermiwash, Fortification, Growth, Yield 


\section{$\vec{x}$}

Renigunta Chainatnya et al, International Journal of Advances in Agricultural Science \& Technology,

Vol.8 Issue.10, October-2021, pg. 60-67

ISSN: 2348-1358

Impact Factor: 6.057

NAAS Rating: 3.77

\section{Introduction}

Cluster bean (Cyamopsistetragonoloba (L).) also known as gaur, guwar, or guvar bean is an annual self-pollinated leguminous crop and belongs to the family Fabaceae (Hymowitz and Matlock, 1963). The origin of the Clusterbean has been suggested in India and Pakistan and tropical Africa (Vavilov, 1951). It is assumed to have developed from the African species Cyamopsis senegalensis. It is a drought tolerant, deep-rooted, annual legume, used as vegetable, Seed, Green manure, Fodder. It is also used for making gum, which is used in Oil refinaries and Petroleum Industry. It is an important short duration (90120 days) crop of high nutritive valve having high nitrogen fixing ability and is grown during kharif as well as summer seasons in arid and semi-arid regions of India. Cluster bean is cultivated mostly in India, Pakistan, USA, Italy, Morocco, Germany, and Spain (Punia et al., 2009).

Young pods are good source of protein, carbohydrate, vitamins ('A' and ' $\mathrm{C}$ '), and important minerals like calcium and iron (Kumar and Singh 2002). The endosperm of guar seed contains an important hydrocolloid named galactomannan. Mucilaginous seed flour is used for making guar gum (galactomannan) utilized in textile, paper, cosmetic and oil industries throughout the world and is a useful absorbent for explosives (Smith, 1976). The galactomannan due to its thicker, binder and stabilizing specific qualities, has a diversified industrial applications viz. paper, food, cosmetics, explosives, mining, petroleum, pharmaceuticals and well drilling etc. Recent rise in demand of guar in International market as a gum is attributed to its use in mining industry and petrochemical, where its use as viscous agent has been revolutionized the petrochemical industry and resulted in considerable increase in global natural gas production (Falasca et al., 2015). The cluster bean gum used as: (i) agriculture - as 


\section{$\vec{\pi}$}

Renigunta Chainatnya et al, International Journal of Advances in Agricultural Science \& Technology,

Vol.8 Issue.10, October-2021, pg. 60-67

anticrushing agent and water retainer, (ii) petroleum industry - as gelling and thickening agent, (iii) textile and juice industry - for sizing, as thickener and stabilizer, (iv) waste water purification - as a gelatinising agent, (v) explosives - waterproofing agent, (vi) mining, and (vii) pharmaceutical industries (Girish et al., 2012). Because of its industrial value, guar seed has great demand from foreign countries like USA, Germany, Britain, Italy, France, UAE, China, Japan, South Africa, Hong Kong and Australia etc. Further, cluster bean meal (husk and germ) are used as high protein cattle feed (Rai and Dharmatti, 2013).

India is the major guar producer accounting for $80 \%$ of the world's production. In India, guar is being grown mainly in arid and semiarid regions of North Western states of Rajasthan, Gujarat, Haryana, Punjab, parts of Uttar Pradesh, Madhya Pradesh and Tamil Nadu. It is grown approximately in an area of3.44 million ha, with a production of 2.21 million tonnes and has productivity of $644 \mathrm{~kg} /$ ha (Directorate of Extension and Statistics, 2012). Rajasthan occupies the largest area under guar cultivation (82.1\%), followed by Haryana (8.6\%), Gujarat (8.3\%) and Punjab (1\%) which in turn produced 64, 22.12 and 2\% guar seeds, respectively (Pathak et al., 2010). Rajasthan is the largest producer accounting for $70 \%$ of total guar production of the country followed by Gujarat, Haryana and Punjab. The productivity of cluster bean ranges from $474 \mathrm{~kg} / \mathrm{ha}$ in Rajasthan to $1200 \mathrm{~kg} / \mathrm{ha}$ in Haryana (Ahlawat et al., 2013). 


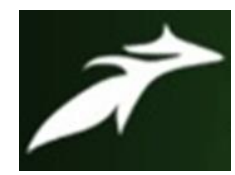

Renigunta Chainatnya et al, International Journal of Advances in Agricultural Science \& Technology,

Vol.8 Issue.10, October-2021, pg. 60-67

\section{Materials and Methods}

The Research study was conducted at experimental research field, Department of Genetics and Plant Breeding, Naini Agriculture Institute, Sam Higginbottom University of Agriculture, Technology and Sciences, Prayagraj during kharif-2019. The experiment was carried out at Field Experimentation Centre of the Department of Genetics and Plant Breeding, Sam Higginbottom University of Agriculture, Technology \& Sciences. Prayagraj (UP) during Kharif-2019.

The source of seed material was obtained from Indian Institute of Pulse Research, Kanpur and the experiment was conducted in Randomized block design (R.B.D) with three replications and the genotype used in this Experiment was GR-6. The data was collected on five randomly selected plants from each plot and measurement of different observations was recorded. The treatments were represented as T0 (Control), $\mathrm{T}_{1}-$ vermin wash 5\% @ 12hrs, $\mathrm{T}_{2}$ vermin wash 10\%@12hrs, $\mathrm{T}_{3}$ - vermin wash 15\% @12hrs, $\mathrm{T}_{4}$ - vermin wash 20\% @ 12hrs, $\mathrm{T}_{5}$ - panchagavya 5\%@12hrs, $\mathrm{T}_{6}$ - panchagavya 10\%@12hrs, $\mathrm{T}_{7}$ - panchagavya 15\% @12hrs, $\mathrm{T}_{8}$ - panchagavya 20\% @ 12hrs, $\mathrm{T}_{9}$ - weed seed extract 5\%@12 hrs, $\mathrm{T}_{10}$ - weed seed extract 10\%@12 hrs, $\mathrm{T}_{11}$ - weed seed extract 15\%@12 hrs, $\mathrm{T}_{12}$ - weed seed extract 20\% @ $12 \mathrm{hrs}$. 


\section{$\vec{x}$}

Renigunta Chainatnya et al, International Journal of Advances in Agricultural Science \& Technology,

Vol.8 Issue.10, October-2021, pg. 60-67

\section{Result and Discussion}

Based on the present study, it can be concluded that the treatment combination T4 (vermiwash 20\% @ 12 hrs) is recommended as the best treatment combination for obtaining the better grow quality parameters in cow pea. Seed quality parameters such as germination \%, root length, shoot length, seedling length seedling fresh weight, Seedling dry weight, vigour index-I and Vigour index-II.

As seed gives positive responses to different concernations of vermiwash, and panchagavya. So it is necessary to strandazie the concentration based on the crop to which it is used.

\section{CONCLUSION}

Treatment combination T4 (vermiwash 20\% @ $12 \mathrm{hrs)} \mathrm{has} \mathrm{maximum} \mathrm{performance} \mathrm{in} \mathrm{all} \mathrm{the} \mathrm{seed} \mathrm{quality}$ parameters it was followed by $\mathrm{T}_{3}$ (vermiwash 15\% @ 12hrs) and least performance was given by T0 (control) while compared with the other treatment combinations. 
Table -1: Mean performance of growth and yield parameters in cluster bean.

\begin{tabular}{|c|c|c|c|c|c|c|c|c|}
\hline Treatments & Germination \% & $\begin{array}{l}\text { Root } \\
\text { length (cm) }\end{array}$ & $\begin{array}{l}\text { Shoot } \\
\text { length }(\mathrm{cm})\end{array}$ & $\begin{array}{l}\text { Seedling } \\
\text { length }(\mathrm{cm})\end{array}$ & $\begin{array}{l}\text { Seedling } \\
\text { fresh weight } \\
(\mathrm{g})\end{array}$ & $\begin{array}{l}\text { Seedling dry } \\
\text { weight (g) }\end{array}$ & $\begin{array}{l}\text { vigour } \\
\text { index-I }\end{array}$ & $\begin{array}{l}\text { vigour } \\
\text { index-II }\end{array}$ \\
\hline T0 & 75.75 & 7.95 & 9.98 & 17.93 & 3.40 & 0.338 & 1358.20 & 27.17 \\
\hline $\mathbf{T 1}$ & 85.50 & 8.61 & 11.88 & 20.49 & 3.65 & 0.363 & 1751.66 & 31.00 \\
\hline $\mathbf{T 2}$ & 85.00 & 9.10 & 11.90 & 21.00 & 4.05 & 0.400 & 1785.00 & 34.00 \\
\hline T3 & 88.00 & 9.43 & 12.15 & 21.58 & 4.25 & 0.430 & 1898.60 & 37.84 \\
\hline T4 & 90.00 & 9.68 & 12.40 & 22.08 & 4.40 & 0.453 & 1986.75 & 40.73 \\
\hline T5 & 86.00 & 8.98 & 11.75 & 20.72 & 3.98 & 0.398 & 1782.14 & 34.19 \\
\hline T6 & 85.50 & 8.90 & 11.75 & 20.65 & 3.88 & 0.387 & 1765.82 & 33.04 \\
\hline T7 & 86.00 & 9.00 & 11.83 & 20.84 & 3.90 & 0.393 & 1791.81 & 33.76 \\
\hline T8 & 87.00 & 9.30 & 12.03 & 21.33 & 4.10 & 0.420 & 1855.28 & 36.54 \\
\hline T9 & 85.00 & 8.08 & 10.53 & 18.61 & 3.77 & 0.377 & 1581.54 & 32.00 \\
\hline T10 & 86.00 & 8.89 & 10.77 & 19.65 & 3.99 & 0.399 & 1689.85 & 34.31 \\
\hline T11 & 85.00 & 8.47 & 10.38 & 18.85 & 3.58 & 0.358 & 1602.36 & 30.39 \\
\hline T12 & 84.00 & 8.53 & 10.42 & 18.95 & 3.42 & 0.342 & 1591.59 & 28.73 \\
\hline
\end{tabular}




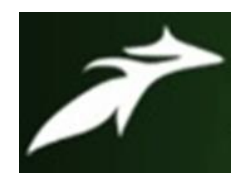

Renigunta Chainatnya et al, International Journal of Advances in Agricultural Science \& Technology,

Vol.8 Issue.10, October-2021, pg. 60-67

ISSN: 2348-1358

Impact Factor: 6.057

NAAS Rating: 3.77

\begin{tabular}{|c|c|c|c|c|c|c|c|c|}
\hline Mean & 85.29 & 8.84 & 11.37 & 20.20 & 3.87 & 0.389 & 1726.20 & 33.36 \\
\hline $\mathrm{CV}$ & 0.70 & 1.207 & 1.00249 & 0.81637 & 1.28053 & 1.69349 & 1.0836 & 1.65266 \\
\hline CD & $0.9806^{*}$ & $0.17618^{*}$ & $0.18818^{*}$ & $0.2724 *$ & $0.08192 *$ & $0.01087 *$ & $30.892 *$ & $0.91053 *$ \\
\hline SE. $m$ & 0.3428 & 0.06159 & 0.06579 & 0.09523 & 0.02864 & 0.0038 & 10.799 & 0.31831 \\
\hline SE. d & 0.4848 & 0.0871 & 0.09304 & 0.13467 & 0.0405 & 0.00538 & 15.237 & 0.45016 \\
\hline
\end{tabular}

* Significant at 5\% level of significance.

\section{References}

[1]. Ahlawat, A, Pahuja, S. K and Dhingra, H. R. 2013. Studies on interspecific hybridization in Cyamopsis species. African J. Agric, 8(27): $3590-3597$.

[2]. AravindJukanti, R. K. Bhatt, Ramavtar Sharma and R.K. Kalia, 2015.Morphological, agronomic, and yield characterization of cluster bean (Cyamopsistetragonoloba L.) germplasm accessions. J. Crop Sci. Biotech. 2015 (March) 18 (1): $00 \sim 00$.

[3]. DAVIES, P. J., 1995, The plant hormones: their nature, occurrence, and functions. In PJ Davies, ed, Plant hormones: Physiology, Biochemistry and Molecular Biology. Kluwer Academic Publishers, Dordrecht, The Netherlands, pp 1 -12.

[4]. Directorate of Extension and Statistics, Government of India. 2012. Area, production, and productivity of clusterbean in India.

[5]. DodlaRajashekar Reddy, P. Saidaiah, K. Ravinder Reddy and Pandravada, S.R. 2017. Mean Performance of Cluster Bean Genotypes for Yield, Yield Parameters and Quality Traits. Int.J.Curr.Microbiol.App.Sci. 6(9): 3685-3693.

[6]. Falasca, S.L., Miranda, C., and Pitta-Alvarez, S. (2015). Modeling an agroclimatic zoning methodology to determine the potential growing areas of Cyamopsistetragonoloba (cluster bean) in Argentina. Advance Applied and Agriculture Sciences, 3: 23-39.

[7]. Girish MH, Gasti VD, Thammaiah N, Kerutagi MG, Mulge R, Shantappa T, Mastiholi AB. 2012. Genetic divergence studies in cluster bean (Cyamopsistetragonoloba (L.) Taub.). Karnataka J. Agric. Sci. 25: 245-247.

[8]. Hari Singh Meena, K.B. Suneetha Devi and Suresh, G. 2016. Yield and profitability of clusterbean (Cyamopsistetragonoloba) as influenced by varieties and crop geometry in semi-arid climate of Andhra Pradesh.Indian Journal of Agronomy. 61 (3): 401 - 403.

[9]. Hymowitz T, Matlock RS. 1963. Cluster Bean in the United States. Oklahoma Agricultural Exper. Station Technical Bull. 611: 1-34.

[10].Kumar D, Singh NB. 2002. Guar in India. Scientific Publishers, Jodhpur, India, 1-5. 


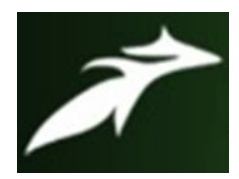

Renigunta Chainatnya et al, International Journal of Advances in Agricultural Science \& Technology, Vol.8 Issue.10, October-2021, pg. 60-67

[11].NRAA, 2014, Potential of Rainfed Guar (Cluster beans) Cultivation, Processing and Export in India. Policy paper No.3 National Rainfed Area Authority, NASC Complex. DPS Marg, New Delhi-110012, India, pp 109.

[12].Pathak, R, Singh, S.K, Singh, M and Henry, A. 2010.Molecular assessment of genetic diversity in cluster bean (Cyamopsistetragonoloba) genotypes. J. Genet. 89: 243-246.

[13].Punia A, Yadav R, Arora P, Chaudhury A. 2009. Molecular and morphophysiological characterization of superior cluster bean (Cymopsistetragonoloba) varieties. J. Crop Sci. Biotechnol. 12: 143-14.

[14].Rai PS, Dharmatti PR. 2013. Genetic divergence studies in cluster bean (Cyamopsistetragonoloba (L.) Taub.). Global J. Sci. Frontier Res. Agri. Veterinary 13: 1-5.

[15].Renugadevi, J. and Vijayageetha, V., 2007, Organic seed fortification in cluster bean (Cyamopsistetragonoloba L.) TAUB.International conference on indigeneous vegetables and Legumes. Acta Hort., 335-338. 